\title{
PHILOSOPHY
}

\author{
THE JOURNAL \\ OF \\ THE ROYAL INSTITUTE OF PHILOSOPHY
}

H. B. A A T T O N

VOL. XXXVII-1962

LONDON:

MAGMILLAN \& CO., LIMITED

ST. MARTIN'S STREET, W.C.

1962 


\section{CONTENTS OF VOLUME XXXVII}

\section{ARTICLES}

PAGE

Adkins, Arthur W. H.-Heidegger and Language - $\quad-\quad$ - $\quad-\quad$ - 229

BAMrrough, ReNFORd.-Plato's Modern Friends and Enemies - $\quad$ - $\quad$ - 97

Brown, K. C.-Hobbes' Grounds for Belief in a Deity - _ _ - $\quad$ - 336

EMмEт, Dorothy.- 'That's That' or Some Uses of Tautology - $\quad$ - $\quad$ - 15

ENGEL, S. MorRIs.-Analogy and Equivocation in Hobbes - - - $\quad-326$

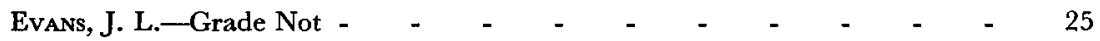

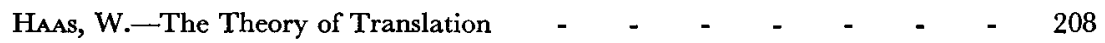

Hunter, Geoffrey.-Hume on 'Is' and 'Ought' - - - - - - - $\quad-148$

Locke, Don.-Ifs and Cans Revisited - - _ - - - - - - $\quad$ - 245

MANSER, A. R.-It Serves You Right - _ $\quad$ - $\quad$ - $\quad$ - $\quad$ - $\quad$ - 293

MaCloskey, H. J.-The Complexity of the Concepts of Punishment _ - 307

Miskovska, V. T.-Comenius on Lexical Symbolism in an Artificial Language - 238

Peters, R. S.-Moral Education and the Psychology of Chàracter - _ - $\quad 37$

Polany, MichasL.-The Unaccountable Element in Science - - $\quad$ - 1

Pole, David.-Morality and the Assessment of Literature - - - - $\quad 193$

Prior, A. N.-The Formalities of Omniscience - - - - - - - $\quad$ - 114

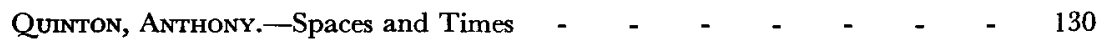

\section{DISGUSSIONS}

Baumer, William H.-Anselm, Truth and Necessary Being - - - - $\quad 257$

EDGLEY, R.-Impartiality and Consistency - $\quad$ - $\quad$ - $\quad$ - $\quad$ - $\quad-\quad 158$

FLew, Anthony.-Are Ninian Smart's Temptations Irresistible? - - - 57

George, F. N.-Minds, Machines and Gödel - $\quad$ - $\quad$ - $\quad$ - $\quad-62$

Halsbury, The Earl or.-Professor Waddington's Naturalistic Ethics - $\quad-63$

Johsson, O. A.-Observing and Disconfirming Propositions: A Reply - $\quad-163$

MAckIE, J. L.-Theism and Utopia - $\quad$ - $\quad$ - $\quad$ - $\quad$ - $\quad$ - $\quad$ - $\quad$ - 153

RAPHAEL, D. D.-Obligations and Rights in Hobbes - - - - $\quad-345$

SMART, N.-Probably - - $\quad$ - $\quad$ - $\quad$ - $\quad$ - $\quad$ - $\quad$ - $\quad$ - 60

WAdDington, C. H.-Naturalism in Ethics and Biology - - - - $\quad-357$

WARRENDER, H.-Obligations and Rights in Hobbes - - - - - $\quad 352$

WHITELEY, C. H.-Minds, Machines and Gödel - _ - - - - $\quad 61$

\section{REVIEW ARTIGLES}

GAmpBell, C. A.-Blanshard's Gifford Lectures (Reason and Goodness. Brand Blanshard) 
Grene, Marjorie.-The Theory of Evolution (The Ascent of Life. T. A. Goudge; The Biological Basis of Human Freedom. T. Dobzhansky) - - - -

LewIS, H. D.-Responsibility and Mental Health (Social Science and Social Pathology. Barbara Wootton) - - - - - - - -

Thomas, D. O.--The Political Philosophy of John Locke (Fohn Locke. Peter Laslett; La Politique Morale de John Locke. Raymond Polin) - - -

PAGE

\section{PHILOSOPHICAL SURVEYS}

Smith, Colin.-Philosophy in France - - - - - - - - - - - 67, 273

Heinemann, F. H.-Philosophy in Germany - - - - - - 71

\section{INSTITUTE NOTES}

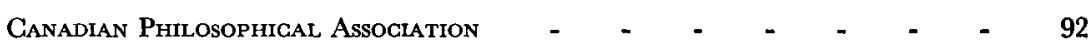

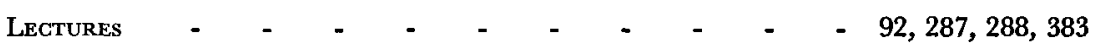

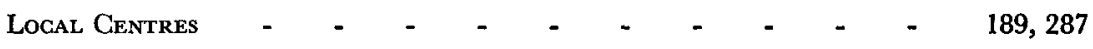

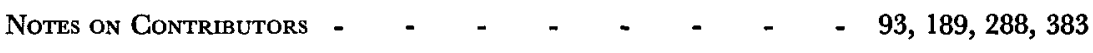

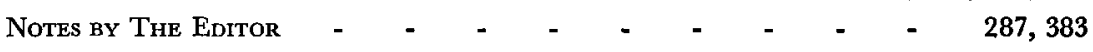

Retirement of Mr L. C. Robertson

Dinner in Honour of Sir D. Ross

Earl Russell, O.M.

Société Britannique de Langue Française $\quad$ - $\quad-\quad-\quad$ - $\quad$ - $\quad-92$

Symoptic Index to the Proceedings of the Aristotelian Society $\quad-\quad-\quad 189$

\section{NEW BOOKS}

Adkıns, A. W. H.-Merit and Responsibility (Richard Robinson) - - - $\quad 277$

Christian, William A.-An Interpretation of Whitehead's Metaphysics (Eva Schaper) . 365

Fischer, William L.—Kritik der Nicht-Euclid'schen Geometrie. (G T. Kneebone) - 177

Gellner, ERNEst.-Words and Things (P. L. Heath) - - - - - 176

GiLlispie, C. C.-The Edge of Objectivity (John Tucker) - - - - - - $\quad 374$

Hagzrahi, Peptra.—The Price of Morality (R. S. Downie) - - - $\quad-371$

Hart, H. L. A. and Honorḱ, A. M.-Causation in the Law (D. D. Raphael) - 83

KLibansky, Raymond (Ed.) - Philosophy in the Mid-Century (A. C. Ewing) - $\quad$ - 75

LEYDEN, W. von.—Remembering (D. W. Hamlyn) - - - - - 178

Melden, A. I.-Free Action (G. N. A. Vesey) - - - - - - $\quad 280$

Minkus, P. A.-Philosophy of the Person (O. R. Jones) - - - - - $\quad 79$

MunN, A. M.-Free-Will and Determinism (John Tucker) - - - $\quad$ - 83

Murray, John Courtney, S.J.-We Hold These Things (G. E. G. Catlin) - 362

NAGEL, ERNEst.-The Structure of Science (G. B. Keene) - - - - - $\quad 372$

NeIBUHR, Reinholo.—Nations and Empire (G. E. G. Catlin) - - - - 362

Pucelle, JEAN.-La Nature et L'Esprit dans la philosophie de T. H. Green (G. R. G.

Mure) - - - - - - - - - - - -279 
RApHate, D. D.-The Paradox of Tragedy (R. W. Hepburn) - - - $\quad-84$

ReID, L. ARnaud. - Ways of Knowledge and Experience (R. W. Hepburn) - $\quad$ - 377

Russell, Bertrand.—Logic and Knowledge: Essays 1901-1950 (T. Honderich) - 77

Samued, Viscount and Dingle, Herbert.-A Threefold Cord. Philosophy, Science and Religion (Leo Robertson) - - - - - - - - - 375

SENDen, M. Von.-Space and Sight (D. W. Hamlyn) - - - $\quad-\quad$ - $\quad-\quad 80$

SimmeL, Georg.-Sociology of Religion (Peter Winch) - - - - - - $\quad 76$

Singer, Marcus G.-Generalisation in Ethics (Jon Wheatley) - - - $\quad-\quad$ - 182

Smart, Ninian.-A Dialogue of Religions (T. R. Miles) - - - - - - $\quad 183$

Spink, J. S.-French Free-Thought from Gassendi to Voltaire (I. W. Alexander) - 369

StACE, W. T.-Mysticism and Philosophy (Leo Robertson) - - - $\quad$ - 179

Strauss, Leo.-What is Political Philosophy (J. G. Rees) - - - - - $\quad 366$

TALmon, J. L.—Political Messianism: Vol. II (A. T. Kolnai) - - - - $\quad 368$

Tatarkiewicz, Wladyslaw.-Philosophical Dissertations offered on his seventieth

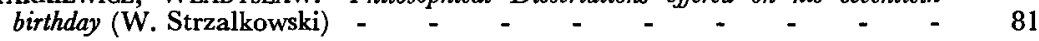

Lubelskiego, Towarzystwo Naukowe Katolickiego Uniwersytelu.-Roczniki Filozoficzne (W. Strzalkowski) -

Urmson, J. O. (Ed.) - The Concise Encyclopaedia of Western Philosophy and Philosophers (A. T. Kolnai) - - - - - - - - - -

WiLson, Joun.--Reason and Morals (O. R. Jones) - _ - - - $\quad$ - 364

YoLton, J. W.-The Philosophy of Science of A. S. Eddington (J. Tucker) - $\quad-\quad 182$ 